\title{
Evaluation of Cerebral Vasoreactivity in Type2 Diabetic Patients by using Transcranial Doppler Ultrasonography (TCD)
} \author{
Hasson *** \\ * M.B.Ch.B Physiology Department / Thi-Qar College of Medicine \\ ** Assistant Proffessor Physiology Department / Kufa College of Medicine \\ *** Professor Clinical Neurology / Middle Euphrate Neuroscience Center \\ *noor.jawad@utq.edu.iq
}

Dr .Noor Jawad Kadhum *' Dr . Zahraa Abdulaali Al- Mudheffer ** \& Dr . Hayder Kadhum

\begin{abstract}
$\underline{\text { Abstract }}$
Background Type 2 diabetes mellitus (T2DM) is associated with an increased risk of cardiovascular and cerebrovascular diseases with high mortality and disability. Cerebral vasomotor reactivity (VMR), one of the most accurate markers of cerebral hemodynamics, has been shown to be impaired in subjects with carotid artery steno-occlusive disease and associated with an increased risk of ischemic events. Transcranial Doppler ultrasonography (TCD) study have been used to investigate cerebral vasoreactivity to identify patients with increased risk and to better plan the treatment.
\end{abstract}

Objective: The aim of study was to assess cerebral vasoreactivity among type 2 diabetes mellitus patients by using transcranial Doppler ultrasonography.

Patients and method: sixty five persons (45 type 2 diabetic patients and 20 normal control) (32 male,33 female) with mean age (46.95 \pm 7.459$)$ enrolled in this study. The study groups are collected randomly from Al Najaf center for Diabetic and endocrine in Al Sader teaching hospital during the time between January 2016 to June 2016. TCD examination was performed in Middle Euphrates Neuroscience Center for all stuied group to assess cerebral vasoreactivity in middle cerebral artery by breath holing test,hyperventilation test (HV), Transient hyperemic test (THRR). (Statistical Package of Social Sciences) SPSS version 23 was used for the statistical analysis.

Results : There was highly significant change of breath holding index BHI between control group and diabetic group (p.value $<0.05)$ and significant change of $\mathrm{HV}$ between control group and diabetic group . Also statistical significant change in THRR in relation to glycemic control(p.value< 0.05 ).

Conclusion : There was significant changes in TCD indices that assessed cerebral vasoreactivity in breath holding index, hyperventilation in type 2 diabetic patients compared with control subjects.

Key words : Diabetes mellitus; Cerebral vasoreactivity; Transcranial Doppler Ultrasonography.

\section{Introduction}




\section{Thi-Qar Medical Journal (TQMJ): Vol.(12), No.(2), 2016 \\ Email:utjmed@utq.edu.iq \\ Web Site: https://imed.utq.edu.iq}

Diabetes mellitus (DM), commonly referred to as a metabolic diseases that result from lack of insulin in person's

blood or when their body has a problem using the insulin it produces (the insulin resistance $)^{[1]}$.Symptoms of high blood sugar include frequent urination(polyuria), increased thirst(polydepsia), and increased hunger(polyphagia). If left untreated, diabetes can cause many complications. ${ }^{[2]}$

Acute complications can include diabetic ketoacidosis,nonketotic hyperosmolar coma, hypoglycemia, or death ${ }^{[2]}$.Serious long-term complications include stroke, heart disease,chronic kidney failure,foot ulcers, and damage to the eyes. $^{[3]}$

Diabetes is due to either the pancreas not producing enough insulin or the cells of the body not responding properly to the insulin produced. ${ }^{[3]}$

Cerebral vasomotor reactivity is defined as a shift between cerebral blood flow or cerebral blood velocity before and after administration of a potent vasodilatory stimulus test, and also it's a unique physiologic characteristic of the brain related to the intrinsic ability of cerebral arteries to alter their caliber in response to a vasoactive stimulus ${ }^{[4]}$.

Diabetes increases the risk for cerebromicrovascular disease, possibly through its effects on blood flow regulation $^{[5]}$. Cerebral microvascular disease in diabetes has been attributed to the effects of chronic hyperglycemia on capillary structure, endothelial reactivity ${ }^{[6]}$, and blood-brain barrier permeability, thus affecting regional metabolism and blood flow regulation ${ }^{[7]}$.Given that more than one million people are diagnosed with diabetes yearly, a Diabetic patients compose roughly $6.3 \%$ of the U.S. population but account for $15-27 \%$ of all incident strokes, based on 2002 estimates ${ }^{[8,9]}$.When considering age-adjusted incidence rates, diabetic patients are 2.9 times as likely to have a stroke compared with nondiabetic patients, a disparity that is seen in multiple racial/geographic groups ${ }^{[10,11,12]}$ This is due specifically to an increase in the rate of ischemic stroke rather than hemorrhagic stroke $^{[13]}$.Most diabetes mellitus (DM) patients are either hyperglycemic and/or exhibit insulin resistance. Both these conditions have been postulated to trigger endothelial dysfunction and atherosclerosis, which contribute to the underlying pathogenesis of stroke ${ }^{[14]}$. This might have served as rationale for previous studies that showed DM to be an independent risk factor of stroke recurrence after a general ischemic stroke ${ }^{[15-17]}$ or TIA ${ }^{[18,19]}$.

Cerebral vasoreactivity has been generally assessed by positron emission tomography (PET) [21] ,single-photon emission computed tomography (SPECT) ${ }^{[20,21]}$, and transcranial Doppler (TCD) ultrasonography [22] .These methods investigate the residual capacity of cerebral arteries to dilate in response to an increase of carbon dioxide $\left(\mathrm{CO}_{2}\right)$, via $\mathrm{CO}_{2}$ inhalation, breath-holding test (BHT), or acetazolamide (ACZ) administration.

An alternative to either PET or SPECT in the evaluation of CVR is TCD ultrasonography, a simple and noninvasive technique that allows rapid measurements of flow velocities in large cerebral arteries. With a vasodilatory stimulus, it has also provided CVR assessment in healthy subjects and in patients with carotid artery steno-occlusive disease ${ }^{[23,24]}$ Studies using TCD have also suggested that impaired CVR is predictive of cerebral ischemic events in such patients ${ }^{[25]}$.Current applications of TCD in adults and children include vasospasm in sickle cell disease ${ }^{[26]}$ ,subarachnoid haemorrhage (SAH) [27], intra- and extracranial arterial stenosis and occlusion ${ }^{[28,29]}$,brain stem death, head injury, raised intracranial pressure (ICP)' intraoperative monitoring [30], impaired vasomotor function and cerebral 


\section{Email:utjmed@utq.edu.iq}

microembolism in right to left cardiac shunts ${ }^{[31]}$.

\section{Methodology}

\section{Study design}

The current study of case-control design included 65 persons (45 type 2 diabetic patients and 20 normal control) with age group (30-60 years) .

\section{Patients}

The patient are collected randomly from $\mathrm{Al}$ Najaf center for Diabetic and endocrine in Al Sader teaching hospital during the time between January 2016 to June 2016.

Inclusion criteria:Type 2 diabetic patients, age of patients was $>30$ years old, and sufficient transtemporal window.

\section{Exclusion}

criteria.:

Hypertension $_{2}$ anaemia ${ }_{2}$ History of asthma or chronic obstructive pulmonary disease (COPD),History of cerebrovascular disease,transient ischaemic attack (TIA), complete stroke or extracranial or intracranial steno-occlusive lesions or altered cerebral hemodynamic,Coronary artery disease,Autonomic neuropathy excluded by doing some tests for patients like heart rate response to deep breathing ,heart rate response to standing up,blood pressure response to standing up and blood pressure response to sustaind handgrip) under supervision of clinical neurologist,Medication like beta blocker and calecium

channel blocker, Smoking and alcoholic, Polycythemia and haematological disease.

\section{Instrument}

By using transcranial Doppler(TCD) pulse wave doppler(M.mode) with $2 \mathrm{MH}$ frequency probe with transcranial software,Atys company French.

\section{Method}

\section{History}

A uniform case sheet was assigned for every participant in the study which
Web Site: https://imed.utq.edu.iq

include age ,sex, history of smoking ,medical history, family history, drug history and DM(duration and treatment).

\section{Examination}

Full examination specially neurological examination was done for all patients including motor, sensory and autonomic examination were undertaken to exclude diabetic neuropathy by consultant neurologist wit experience in the field.

Body weight and height were measured by digital weight and height scale.body mass index was calculated according to the following equation ${ }^{[32,33,34]}$ ( $\mathrm{BMI}=$ wight $(\mathrm{Kg}) /$ height $\left(\mathrm{m}^{2}\right)$.Blood pressure measurement and ECG also done for all study groups.

\section{Biochemical analysis}

Sample of blood were taken from all study group for laboratory investigation fasting blood sugar (after 12 hour overnight fasting ) and $\mathrm{HbA} 1 \mathrm{C}$.

\section{TCD examination}

TCD was performed in supine position. Probe was positioned over each transtemporal window, arteries of the Willis circle were insonated by standard protocol and mean blood flow values (MBFV) were recorded.

Vasoreactivity to $\mathrm{CO}_{2}\left(\mathrm{CO}_{2} \mathrm{R}\right)$ was measured using 1.5 minutes of hyperventilation. . Before proceeding to the definitive recording, all subjects were trained to perform the procedure of breath holding and hyperventilation correctly.

Determination of vasomotor reserve (VMR) with the transcranial Doppler-Co2 (TCD-CO2) by three tests:

1. Breath holding test for induction of cerebral vasodilitation by breath hold for 40 seconds. 
2. Hyperventilation test by asking the patient to hyperventilate for 1.5 minuts.

3. Transient hyperemic test by pressure on common carotid artery and then relive the pressure ,this test for assess cerebral autoregulation.

- $\quad$ Findings of our study are taken to study the relationship of breath holding index,hyperventilation, transient

hyperaemic response by TCD with age ,gender, BMI, HBA1C. TCD parameters or indices and CVR were studied among type 2 diabetes compare with control.

\section{5:Statistical analysis}

Data were expressed as mean \pm SD.

Independent-sample t-test had been used to compare the difference between diabetic and normal groups. Statistical analysis was performed by using computer programs Statistical Package of Social Sciences (SPSS) version 23 and Microsoft excel in data performing. (statistical significance was obtained at $\mathrm{p}<0.05$ value).

\section{$\underline{\text { Results }}$}

Table 1: Demographic and clinico- biochemical characteristics of studied population shows that the current study included 65 subjects (45 subjects were known case of T2DM) and 20 ( as control group ).

\begin{tabular}{|c|c|c|c|}
\hline Variables & Control & Diabetic & Total \\
\hline Age $(\mathbf{3 0 - 4 5}$ yrs $)$ & $11(55.0 \%)$ & $16(35.6 \%)$ & $27(41.5 \%)$ \\
\hline $\mathbf{( 4 6}$ and more $)$ & $9(45.0 \%)$ & $29(64.4 \%)$ & $38(58.5 \%)$ \\
\hline Sex $\quad$ F & $10(50.0 \%)$ & $23(51.1 \%)$ & $33(50.8 \%)$ \\
\hline M & $10(50.0 \%)$ & $22(48.9 \%)$ & $32(49.2 \%)$ \\
\hline BMI <25 & $4(20.0 \%)$ & $5(11.1 \%)$ & $9(13.8 \%)$ \\
\hline $\mathbf{2 5}$ & $16(80 \%)$ & $40(88.9 \%)$ & $56(86.2 \%)$ \\
\hline HbA1C $<7$ & $20(100 \%)$ & $12(26.7 \%)$ & $32(49.23)$ \\
\hline$\geq 7$ & $0(0.0 \%)$ & $33(73.3 \%)$ & $33(50.77)$ \\
\hline
\end{tabular}

Table 2: Cerebral vasoreactivity of diabetic patients versus control goup shows that there was a highly significant statistical association of BHI between control group and diabetic group (p.value $<0.05$ ) and significant change of HV between control group and diabetic group while no significant change in THRR between study group.

\begin{tabular}{|l|l|l|c|}
\hline Parameter & $\begin{array}{l}\text { Diabetic } \\
\text { No\%=45 }(\mathbf{6 9 \%}) \\
\text { Mean } \pm \text { SD }\end{array}$ & $\begin{array}{l}\text { Control } \\
\text { No\%=20(31\%) } \\
\text { Mean } \pm \text { SD }\end{array}$ & P-value \\
\hline Breath holding index & $0.4604 \pm \cdot .24493$ & $0.7360 \pm 0.23493$ & 0.000 \\
\hline Hyperventilation & $23.8786 \pm 12.93330$ & $28.0000 \pm 6.4563$ & 0.042 \\
\hline Transient hyperaemic response & $1.140 \pm 0.154$ & $1.17 \pm 0.171$ & 0.546 \\
\hline
\end{tabular}


Table 3: Effect of gender on Cerebral vasoreactivity in diabetic patient shows that there was no significant statistical association in BHI,HV,THRR p.value> 0.05 in male and female diabetic patients.

\begin{tabular}{|l|l|l|l|l|}
\hline Parameter & Sex & $\begin{array}{l}\text { No. } \\
\text { \% }\end{array}$ & Mean \pm SD & P-value \\
\hline Breath holding index & M & $22(49 \%)$ & $0.4968 \pm 0.24175$ & 0.335 \\
& F & $23(51 \%)$ & $0.4291 \pm 0.25062$ & \\
\hline Hyperventilation & M & $22(49 \%)$ & $28.3750 \pm 11.48906$ & 0.926 \\
& F & $23(51 \%)$ & $28.0204 \pm 13.69641$ & \\
\hline Transient hyperaemic response & M & $22(49 \%)$ & $1.1714 \pm 0.193$ & 0.225 \\
& F & $23(51 \%)$ & $1.1152 \pm .09940$ & \\
\hline
\end{tabular}

Table 4: Effect of age on cerebral vasoreactivity in diabetic patient shows that there was no significant statistical change in BHI,HV,THRR ( p.value> 0.05) between age groups in diabetic patients.

\begin{tabular}{|l|l|l|l|l|}
\hline Parameter & Age & $\begin{array}{l}\text { No. } \\
\%\end{array}$ & Mean \pm SD & P-value \\
\hline $\begin{array}{l}\text { Breath holding } \\
\text { index }\end{array}$ & $\begin{array}{l}(30-45) \\
(46-65)\end{array}$ & $\begin{array}{l}16(36 \%) \\
29(64 \%)\end{array}$ & $\begin{array}{l}0.5075 \pm 0.29659 \\
0.4345 \pm 0.21256\end{array}$ & 0.344 \\
\hline Hyperventilation & $(30-45)$ & $16(36 \%)$ & $32.4856 \pm 13.64855$ & 0.088 \\
& $(46-65)$ & $29(64 \%)$ & $25.8259 \pm 11.41558$ & \\
\hline $\begin{array}{l}\text { Transient } \\
\text { hyperaemic } \\
\text { response }\end{array}$ & $(30-45)$ & $16(36 \%)$ & $1.1038 \pm 0.10720$ & 0.211 \\
\hline
\end{tabular}

Table 5: Effect of glycemic control on cerebral vasoreactivity in diabetic patients shows evaluation of CVR in diabetic goup in relation to glycemic control. There is no significant statistical association in BHI,HV between two groups of glycemic control but show statistical significant change in THRR (p.value $<0.05$ ).

\begin{tabular}{|l|l|l|l|l|}
\hline Parameter & HBA1C & $\begin{array}{l}\text { No. } \\
\text { \% }\end{array}$ & Mean \pm SD & P-value \\
\hline Breath holding index & $\begin{array}{l}\text { Controlled } \\
\text { DM }\end{array}$ & $\begin{array}{l}13(29 \%) \\
32(71 \%)\end{array}$ & $\begin{array}{l}0.4162 \pm .26918 \\
0.4784 \pm .23652\end{array}$ & 0.442 \\
& $\begin{array}{l}\text { uncontrolled } \\
\text { DM }\end{array}$ & & & \\
\hline Hyperventilation & Controlled & $13(29 \%)$ & $29.0192 \pm 14.412$ & 0.782 \\
& $\begin{array}{l}\text { DM } \\
\text { uncontrolled } \\
\text { DM }\end{array}$ & $32(71 \%)$ & $27.8584 \pm 11.907$ & \\
\hline
\end{tabular}




\begin{tabular}{|l|l|l|l|l|}
\hline Transient & Controlled & $13(29 \%)$ & $1.2146 \pm .21616$ & 0.044 \\
hyperaemic response & DM & $32(71 \%)$ & $1.1134 \pm .11152$ & \\
& $\begin{array}{l}\text { uncontrolled } \\
\text { DM }\end{array}$ & & & \\
\hline
\end{tabular}

Table 6 : Effect of body mass index on cerebral vasoreactivity in diabetic patients shows that there was no significant stastical association in BHI, HV ,THRR in two group of assessment of body mass index (BMI) but the majority of patients in group had a BMI > 25 .

\begin{tabular}{|l|l|l|l|l|}
\hline Parameter & BMI & $\begin{array}{l}\text { No. } \\
\%\end{array}$ & Mean \pm SD & P-value \\
\hline Breath holding index & $\begin{array}{l}\text { Normal BMI } \\
\text { Over weight }\end{array}$ & $\begin{array}{l}10(22 \%) \\
35(78 \%)\end{array}$ & $\begin{array}{l}0.4500 \pm .19568 \\
0.4634 \pm .25973\end{array}$ & 0.881 \\
\hline Hyperventilation & $\begin{array}{l}\text { Normal BMI } \\
\text { Over weight }\end{array}$ & $\begin{array}{l}10(22 \%) \\
35(78 \%)\end{array}$ & $\begin{array}{l}32.777 \pm 13.72742 \\
13.72742 \pm 12.0469\end{array}$ & 0.193 \\
\hline $\begin{array}{l}\text { Transient hyperaemic } \\
\text { response }\end{array}$ & $\begin{array}{l}\text { Normal BMI } \\
\text { Over weight }\end{array}$ & $\begin{array}{ll}10(22 \%) \\
35(78 \%)\end{array}$ & $1.1100 \pm .11804$ & 0.453 \\
& & & & \\
\hline
\end{tabular}

\section{$\underline{\text { Discussion }}$}

In this study, 65 subjects $(45 \mathrm{~T} 2 \mathrm{DM} \& 20$ control ) studied to evaluate cerebral vasoreactivity through middle cerebral artery by measuring breath holding index and subsequent hyperventilation and transient hyperaemic response.

\section{* Comparison of cerebral vasoreactivity of diabetic patients versus control group}

In current study, which involved $\leqslant 5$ type 2 diabetic patients, reveals significant change of BHI,HV (p.value<0.05) which suggest impaired cerebral vasoreactivity, compared to $r$. control group. The results are in agreement with results of Paola Palazzo et al., 2013 $3^{[35]}$, who reported that impaired cerebral vasoreactivity in type 2 diabetic patients in compared with control group.This may explained by impaired VMR in this selected population of T2DM patients strongly suggests that insulinresistance has an impact on vascular function, even in the absence of metabolic derangement. Activation of oxidative stress pathways, by increased glucose variability $^{[36]}$, might also have a negative impact on endothelial function.

Effect of age and gender on cerebral vasoreactivity in diabetic patient.

In our study,show no statistical significant change in BHI,HV,THRR p.value> 0.05 between age groups in diabetic patients. This may explained by effect of diabetes that overcomes the physiological effect of age and gender on cerebral vasoreactivity .

This result agree with David Last et $a l ., 2007^{[37]}$, which adressed the regional effects of type 2 diabetes and associated conditions on cerebral tissue volumes and cerebral blood flow (CBF) regulation,the result demonstrate no differ in age,sex between diabetic and control groups. This finding agree with Yamamoto et al. ,1980 [38] examined the effect of aging on cerebral vasodilator responses to hypercapnia and found that mean $\mathrm{CBF}$ in the elderly was $\approx 10 \%$ to $20 \%$ less than in young volunteers and that vasodilatory response to hypercapnia in elderly patients 


\section{Thi-Qar Medical Journal (TQMJ): Vol.(12), No.(2), 2016

without risk factors was similar to that in young volunteers.

But the results disagree with Vladimira Vuleti et al.,2011 ${ }^{[39]}$, to assess cerebral vasoreactivity (CVR) in type 2 diabetes mellitus (DM2)by transcranial doppler and factors which may influence on it. In DM2 group they found a significant correlation between BHI and age $(\mathrm{p}=0.0004)$, fasting glycemia $(\mathrm{p}=0.04)$, and albuminuria $(\mathrm{p}=0.04) \quad$ (creatinine clearance in multivariate analysis $(\mathrm{p}=0.007))$.

\section{* Effect of glycemic control on cerebral vasoreactivity in diabetic patient}

Analysis of effect of glycemic control on cerebral vaoreactivity in diabetic patients did not reveal any siginificant correlation by BHI,HV,but statistical significant changes in THRR.

This result agree with Vladimira Vuleti et al.,2011, to assess cerebral vasoreactivity (CVR) in type 2 diabetes mellitus (DM2)by transcrainial doppler and factors that did not find any correlation between the HbA1c and CVR in diabetic patients by BHI.

\section{* Effect of body mass index on cerebral vasoreactivity in diabetic patient.}

In current study, there was no significant change in BHI, HV ,THRR in assessment of body mass index (BMI).This result disagree with Magdy Selim,et al.,2008 ${ }^{[40]}$, which is cross sectional study aimed to determine the effects of high body mass index (BMI) on cerebral blood flow regulation in patients with type- 2 diabetes mellitus, hypertension, and stroke that include 90 controls, 30 diabetics, 45 hypertensives, and 32 ischemic stroke patients who underwent transcranial Doppler for evaluation of blood flow velocities (BFV) in the middle cerebral arteries (MCA) and cerebrovascular resistance (CVR) during supine rest and head-up tilt. On the other hand,this findings inconsistent with Kadoi, Y., et al.,2003 [41] that show that HbA1c is related to an impaired vasodilatory response to $\mathrm{CO}_{2}$. This discrepancy might be due in part to differences in demographic data like age,sex, duration of diabetes, exclusion criterian in addition to collection of sample like Kadoi, Y., et al.,2003 used in their study diabetic patients with retinopathy.

\section{Conclusion}

There was significant association in TCD indices that assessed cerebral vasoreactivity (BHI,HV,THRR) in type2 diabetic patients compared with control subjects. These results may carry important implications for the preventive strategies in treatment of DM2 patients.

While no correlation with age,sex,BMI.

\section{Recommendations}

1. Large sample size to get awide range to study cerebral vasoreactivity.

2. TCD examination should be performed periodically as a routine basis for all diabetic patients because the TCD is the most accurate method in the evaluation and monitoring of the cerebral haemodynamic changes in the diabetic microangiopathy, especially silent ones.

3. Long-term prospective studies should be performed in order to evaluate the clinical course of cerebrovascular impairment and endothelial dysfunction in the natural history of diabetic disease.

\section{$\underline{\text { References }}$}




\section{Email:utjmed@utq.edu.iq}

1. WHO, Diabetes Fact sheet No. 312. WHO: October 2013. Retrieved March 25, 2014.

2. Kitabchi AE, Umpierrez GE, Miles JM, Fisher JN. Hyperglycemic crises in adult patients with diabetes. Diabetes care. 2009 Jul 1;32(7):133543.

3. Shoback, edited by David G. Gardner, Dolores "Chapter 17".Greenspan's basic \& clinical endocrinology (9th ed.). New York: McGrawHill Medical. (2011). ISBN 0-07-162243-8.

4. Schwertfeger N, Neu P, Schlattmann P, Lemke $\mathrm{H}$, Heuser I, Bajbouj M. Cerebrovascular reactivity over time course in healthy subjects. Journal of the Neurological Sciences. 2006;249(2):135-139.

5. Xu WL, Qiu CX, Wahlin A, Winblad B, Fratiglioni L: Diabetes mellitus and risk of dementia in the Kungsholmen project: a 6-year follow-up study. Neurology 63: 11811186, 2004.

6. Trauernicht AK, Sun H, Patel KP, Mayhan WG. Enalapril Prevents Impaired Nitric Oxide Synthase-Dependent Dilatation of Cerebral Arterioles in Diabetic Rats. Stroke. 2003 Nov 1;34(11):2698-703.

7. Makimattila S, Malmberg-Ceder K, Hakkinen AM, Vuori K, Salonen O, Summanen P, YkiJarvinen H, Kaste M, Heikkinen S, Lundbom $\mathrm{N}$, Roine RO: Brain metabolic alterations in patients with type 1 diabetes-hyperglycemiainduced injury. J Cereb Blood Flow Metab 24:1393-1399, 2004.

8. Kissela BM, Khoury J, Kleindorfer D, Woo D, Schneider A, Alwell K, Miller R, Ewing I, Moomaw CJ, Szaflarski JP, Gebel J, Shukla R, Broderick JP: Epidemiology of ischemic stroke in patients with diabetes: the Greater Cincinnati/Northern Kentucky Stroke Study. Diabetes Care 2005.28:355-359.

9. Centers for Disease Control and Prevention: National Diabetes Fact Sheet: General Information and National Estimates on Diabetes in the United States, 2002. Atlanta, GA, Department of Health and Human Services, Centers for Disease Control and Prevention Atlanta, 2003.

10. Grau AJ, Weimar C, Buggle F, Heinrich A, Goertler M, Neumaier S, Glahn J, Brandt T, Hacke W, Diener HC: Risk factors, outcome, and treatment in subtypes of ischemic stroke: the German stroke data bank. Stroke 32:25592566, 2001

11. Kissela B, Schneider A, Kleindorfer D, Khoury J, Miller R, Alwell K, Woo D, Szaflarski J, Gebel J, Moomaw C, Pancioli A. Stroke in a biracial population the excess burden of stroke among blacks. Stroke. 2004 Feb 1;35(2):42631 .
Web Site: https://imed.utq.edu.iq

12. Ottenbacher KJ, Ostir GV, Peek MK, Markides KS. Diabetes mellitus as a risk factor for stroke incidence and mortality in Mexican American older adults. The Journals of Gerontology Series A: Biological Sciences and Medical Sciences. 2004 Jun 1;59(6):M640-5.

13. Karapanayiotides TH, Piechowski-Jozwiak B, Van Melle G, Bogousslavsky J, Devuyst G. Stroke patterns, etiology, and prognosis in patients with diabetes mellitus. Neurology. 2004 May 11;62(9):1558-62.

14. Saad MI, Abdelkhalek TM, Saleh MM, Kamel MA, Youssef M, Tawfik SH, et al. Insights into the molecular mechanisms of diabetesinduced endothelial dysfunction: focus on oxidative stress and endothelial progenitor cells. Endocrine. 2015; 50:537-567.

15. Shou J, Zhou L, Zhu S, Zhang X. Diabetes is an Independent Risk Factor for Stroke Recurrence in Stroke Patients: A Metaanalysis. J Stroke Cerebrovasc Dis. 2015; 24(9):1961-1968.

16. Jia Q, Zhao X, Wang C, Wang Y, Yan Y, Li $\mathrm{H}$, et al. Diabetes and poor outcomes within 6 months after acute ischemic stroke: the China National Stroke Registry. Stroke. 2011; 42(10):2758-2762.

17. Diener HC, Ringleb PA, Savi P. Clopidogrel for the secondary prevention of stroke. Expert Opin Pharmacother. 2005; 6(5):755-764.

18. Johnston SC, Rothwell PM, Nguyen-Huynh MN, Giles MF, Elkins JS, Bernstein AL, et al. Validation and refinement of scores to predict very early stroke risk after transient ischaemic attack. Lancet. 2007;369(9558):283292. .

19. Merwick A, Albers GW, Amarenco P, Arsava EM, Ay H, Calvet D, et al. Addition of brain and carotid imaging to the $\mathrm{ABCD}^{2}$ score to identify patients at early risk of stroke after transient ischaemic attack: a multicentre observational study. Lancet Neurol. 2010; 9(11):1060-1069.

20. Nezu T, Yokota C, Uehara T, et al. Preserved acetazolamide reactivity in lacunar patients with severe white-matter lesions: ${ }^{15} \mathrm{O}$-labeled gas and $\mathrm{H}_{2} \mathrm{O}$ positron emission tomography studies. Journal of Cerebral Blood Flow \& Metabolism. 2012;32:844-850.

21. Aso K, Ogasawara K, Sasaki M, et al. Preoperative cerebrovascular reactivity to acetazolamide measured by brain perfusion SPECT predicts development of cerebral ischemic lesions caused by microemboli during carotid endarterectomy. European Journal of Nuclear Medicine and Molecular Imaging. 2009;36(2):294-301. 


\section{Email:utjmed@utq.edu.iq}

22. Willie CK, Colino FL, Bailey DM, et al. Utility of transcranial Doppler ultrasound for the integrative assessment of cerebrovascular function. Journal of Neuroscience Methods. 2011;196(2):221-237

23. Schwertfeger N, Neu P, Schlattmann P, Lemke $\mathrm{H}$, Heuser I, Bajbouj M. Cerebrovascular reactivity over time course in healthy subjects. Journal of the Neurological Sciences. 2006;249(2):135-139.

24. Markus H, Cullinane M. Severely impaired cerebrovascular reactivity predicts stroke and TIA risk in patients with carotid artery stenosis and occlusion. Brain. 2001;124(3):457-467.

25. Yeo LL, Sharma VK. Role of transcranial doppler ultrasonography in cerebrovascular disease. Recent Patents on CNS Drug Discovery. 2010;5(1):1-13.

26. Adams RJ. TCD in sickle cell disease: an important and useful test. Pediatric Radiology. 2005;35(3):229-234.

27. Rigamonti A, Ackery A, Baker AJ. Transcranial Doppler monitoring in subarachnoid hemorrhage: a critical tool in critical care. Canadian Journal of Anesthesia. 2008;55(2):112-123.

28. Arenillas JF, Molina CA, Montaner J, Abilleira S, González-Sánchez MA, Álvarez-Sabín J. Progression and clinical recurrence of symptomatic middle cerebral artery stenosis: a long-term follow-up transcranial Doppler ultrasound study. Stroke. 2001;32(12):28982904. Christou I, Felberg RA, Demchuk AM, et al. A broad diagnostic battery for bedside transcranial Doppler to detect flow changes with internal carotid artery stenosis or occlusion. Journal Neuroimaging.2001;11(3):236-242.

29. Moreno JA, Mesalles E, Gener J, et al. Evaluating the outcome of severe head injury with transcranial Doppler ultrasonography. Neurosurgical Focus. 2000;8(1):1-7.

30. Pennekamp CWA, Moll FL, de Borst GJ. The potential benefits and the role of cerebral monitoring in carotid endarterectomy. Current
Web Site: https://imed.utq.edu.iq

Opinion in Anaesthesiology. 2011;24(6):693697.

31. World health organization .Appropriate body mass index for asian population and its implications for policy and intervention stratigies.The lancet.2004:157-163. Bray GA.Obesity in Nutrition .Harrison's principles of internal medicine. $17^{\text {th }}$ edit.McGrewHills.2008.

32. Garabed E.The average man and indeces of obesity

.Nephrol.Dial.Transplant.2008;23(1):47-51.

33. Palazzo, Paola, et al. "Cerebral hemodynamics and systemic endothelial function are already impaired in well-controlled type 2 diabetic patients, with short-term disease." PloS one 8.12 (2013): e83287.

34. Di Flaviani A, Picconi F, Di Stefano P, Giordani I, Malandrucco I, et al. (2011) Impact of glycemic and blood pressure variability on surrogate measures of cardiovascular outcomes in type 2 diabetic patients.Diabetes Care 34: 1605-9.

35. Last D, Alsop DC, Abduljalil AM, Marquis RP, De Bazelaire C, Hu K, Cavallerano J, Novak V. Global and regional effects of type 2 diabetes on brain tissue volumes and cerebral vasoreactivity. Diabetes care. 2007 May 1;30(5):1193-9.

36. Yamamoto M, Meyer JS, Sakai F, Yamaguchi F. Aging and cerebral vasodilator responses to hypercarbia. Arch Neurol. 1980; 37: 489-496.

37. Vuletić, V., Čengić, L., Bašić, S., Sporiš, D., Rahelić, D. and Demarin, V., 2011. Impaired cerebral vasoreactivity in type 2 diabetes mellitus. Collegium antropologicum, 35(1), pp. 27-31.

38. Selim M, Jones R, Novak P, Zhao P, Novak V. The effects of body mass index on cerebral blood flow velocity. Clinical Autonomic Research. 2008 Dec 1;18(6):331-8.

39. Kadoi, Y., Hinohara, H., Kunimoto, F., Saito, S., Ide, M., Hiraoka, H., Kawahara, F. and Goto, F., 2003. Diabetic patients have an impaired cerebral vasodilatory response to hypercapnia under propofol anesthesia. Stroke, 34(10), pp.2399-2403 


\section{تقييم تفاعلية الاوعية الدموية الدماغية لدى مرضى السكري من النوع

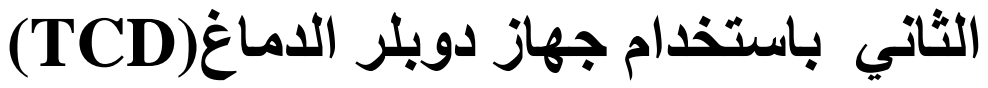

حيدر كاظم حسون

زهراء عبدالعالي المظفر

نور جواد كاظم

\section{الخلاصة}

خلفية الدراسة: - ماسة.

يرتبط النوع الثاني من داء السكري مع مع زيادة مخاطر الإصابة بأمر اض القلب والإية والأوعية الدموية

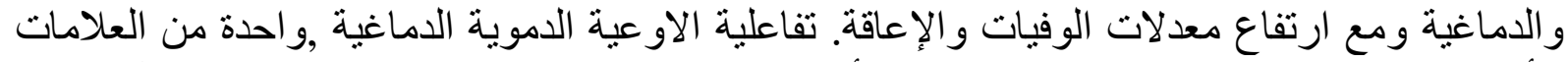

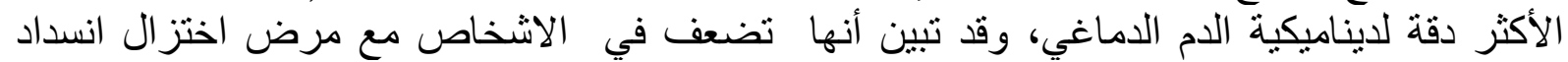

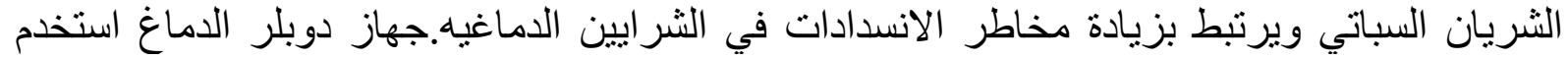

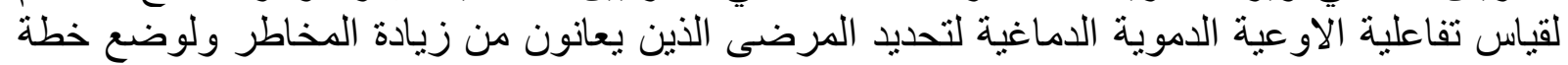

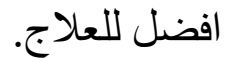

الهلف: الهدف من الدراسة هو تقييم تفاعلية الاوعية الدموية الدماغيه لدى مرضى داء السكري من النوع الثناني باستخدام جهاز دوبلر الاماغ.

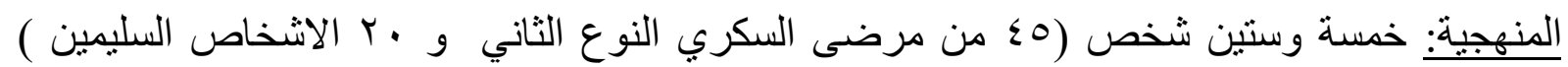

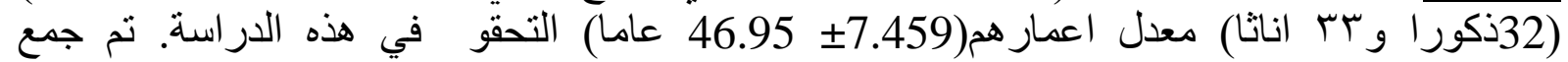

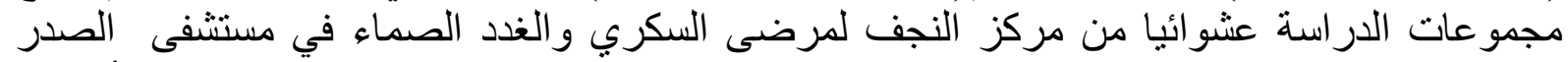

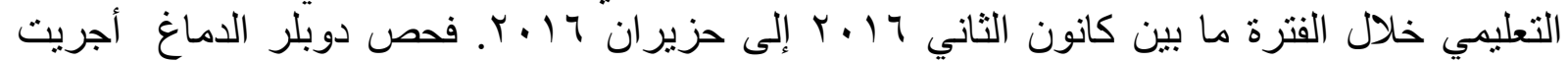

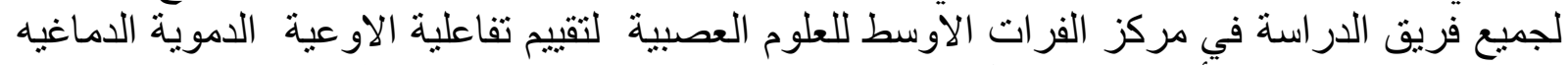

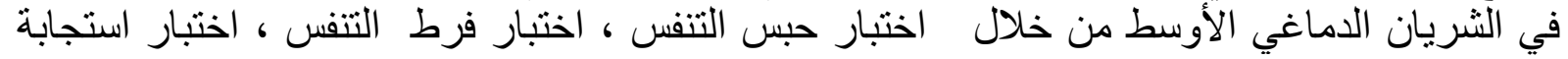

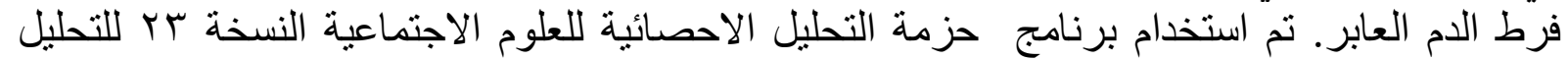
الإحصائي.

النتائج: اظهرت النتائج ان هنالك تغيير كبير في اختبار حبس التتفس ربين مجموعة مرضى السكري

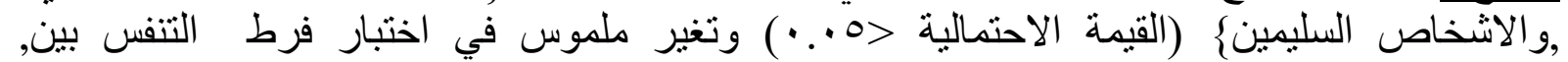

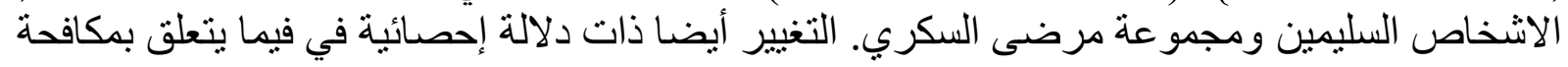

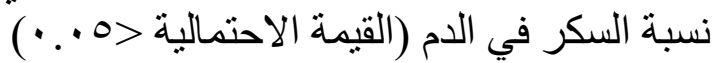

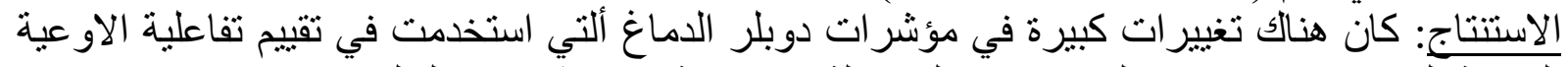

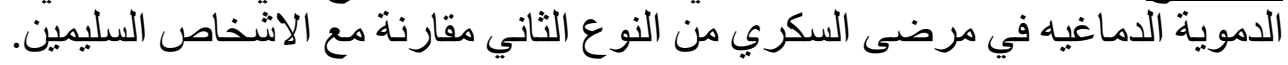

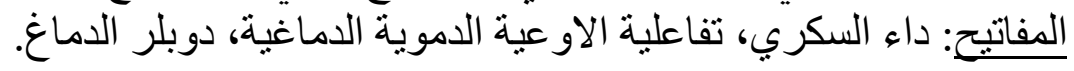


Thi-Qar Medical Journal (TQMJ): Vol.(12), No.(2), 2016 Email:utjmed@utq.edu.iq

Web Site: https://imed.utq.edu.iq 